\title{
Reconstructing meaning without redesigning products: The case of the Serie7 chair
}

\begin{abstract}
What constitutes product value has been traditionally attributed to aesthetics, elicitation of emotions, quality and style. The design driven innovation literature, instead, suggests that meanings are sought and designed as a way to deliver value to customers; however, it infers that product meanings evolve when a product is redesigned. What happens to product meanings when products have not been redesigned but have remained successful in the market over a number of decades? This study identifies how meanings attached to long-lasting products have changed in spite of a consistent form and shape. Using Actor-Network Theory (ANT) as an analytical framework to understand the relationship between meaning and the materiality of the object, an ethnography of the Serie7 chair was conducted. Weekly site visits; formal and informal interviews were coupled with observations and supplemented with 60 years of historic information. We contribute to the innovation literature by demonstrating the importance of materiality in constructing product meaning over long periods. We analysed the Serie7 in four different periods of its life, looking at meaning of the chair at the time, and how management proposed new meanings through a translation process, connecting otherwise disconnected things.
\end{abstract}

Keywords: Design Management, Value, Meaning, Actor-Network Theory, Product Design

\section{Introduction}

Creating value for customers is one of the ultimate goals of new product design and development (Kim, Lee \& Park 2013). To achieve this, a number of approaches have been proposed (Gabrielsen, Kristensen, \& Zaichkowsky, 2010), and it emerges that design is not an 
add-on at the end of a process, but a driver for innovation and designing-in values (Walsh, Roy \& Bruce, 1988; Cooper et al.; 2003; Walsh et al, 1993; Veryzer, 2005).

Looking into the design driven literature, we realised that there is a relationship between value and meaning. Thus, we started to wonder what constitutes the values of a designed product and how are values created in products, which have been consistently successful over time. To further understand the relationship between value and meaning, we initially built on design driven innovation (DDI) (Verganti, 1997), and Krippendorff's (2006) theories on the semantic turn. In DDI value is associated with the meaning of a new product and provides a framework to explain how companies can successfully propose new experiences and new interpretations for what a product is meant (Verganti \& Öberg, 2013).

This paper uses an illustrative case of the iconic Scandinavian design, the Serie7, the most commonly sold chair in the world (Faith, 2013), which has been in the market for more than 60 years. From a preliminary analysis, we infer that the meaning of the design was not blackboxed, but mobilised in a continuous discussion of struggle and terrain. The persons speaking on behalf of the design (chairs) were mobilising and displacing different meanings to talk about the chair.

Krippendorff (2011) proposes the trajectory of artificiality in which a product moves up through its meanings, which "are invented and brought into play by people needing to cope with particular artefacts or achieve something with them" (pg. 414): a design moves on trajectory that starts with the product, and moves up to goods, services and identities; interfaces; multi-user system; projects; and discourses. However, he writes: "Their 
materiality — of what artefacts are made — is secondary and their functionality — how parts work together-may well remain hidden to their users" (pg. 415). This is an interesting but, at the same time, challenging preposition: whereas it might be that not all the consumers are interested in the material part of a design; at the same time, it is not possible to dismiss the materiality of objects, as the recent literature on neo-materialism has demonstrated (Puig de la Bellacasa, 2017; Gasparin \& Neyland, 2017). Thus, whilst we might agree that the design's value creates the meaning, we aim to advance this research field, by expanding what constitute the meaning of the design by taking into consideration its materiality.

Research on DDI has largely evidenced breakthrough products derive from proposing products with new meanings for the consumers (Verganti 1997). Creating radical new meanings is now a widely accepted field of research and it has been studied not only in design products (Verganti, 2009) but also in car dealerships (Bellini et al, 2017) and in the smartphone apps industries (Buganza, Dell' Era and Verganti, 2015; Green and Cluley, 2014). The focus of this research is almost always on new products and the services aligned to them, or on products that are re-interpreted. For example, Verganti (2009) established how FIAT managed to sustain the Panda for over 30 years by reinventing new meanings and updating the shape and form in response to the new meaning.

The design driven innovation research on product meaning does not currently extend to products that retain their shape and form. Therefore, taking a new materialism research position. Based on Actor-Network Theory (ANT) (for example, Akrich, Callon \& Latour, 2002 a,b; Christiansen \& Varnes, 2007; Christiansen et al, 2010; Holzer, 2012, Gasparin \& Green, 2016; and, Christiansen \& Gasparin, 2016) we extend this interesting area of research that to contribute to the discussion of how could managers manage long-lasting products that have been in the marketplace for multiple generations without changing their shape and form. 
We propose the following contributions:

- Conceptually, we advance the theory on meaning by bringing notions from ANT (Actor-Network Theory) that allow us to establish a relationship between utterances and features. The features of a product are performative in explaining the materiality; the new meaning is created through a translation process, by connecting otherwise disconnected features of the product. This means that, compared to Krippendorff's argument, within ANT's framework it is possible to design meanings because they are not only a linguistic operation, but also a translation to create connections between different features that the end-users would not have been able to make.

- Empirically, we establish that the meaning of products is not inherent to the product. Values are interpreted not as enduring but as perpetually modified (Latour, Harmon \& Erdélyi, 2011). Meanings are, therefore, not embedded in a product, and nor a priori determined, but repeatedly created, and design managers design the value creation process by translating new meanings of the design in different markets.

- Managerially, working with the meaning of the product could contribute to the sustainability as organisations might engage in creating long-lasting products, having a positive economic and environmental impact (Esslinger, 2011).

In the next section, we present the theoretical background on constructing meanings, first from a design driven and then from an ANT (actor network theory) perspective, which is used as analytical framework to understand the relationship between the materiality of the design and its meaning. This section is followed by the method and the analysis. The article concludes with a discussion punctuated through episodes, which reflect periods of the case products evolution, managerial implications and recommendations for further research. 


\section{Theoretical background}

\section{Designing new meanings}

According to DDI, design is embedded in discourse, which comes in the form of narratives.

These narratives are composed by language, semantic and meaning (Krippendorff, 1989; Verganti, 2011). While the semantic relates to the symbolic qualities of form, those made sense cognately by the end user of the product. Language helps to articulate feelings and emotions and to make sense of the design consumers have in front of them (Krippendorff, 1989). The idea that consumers do not respond to what things are, but to what they mean and they act accordingly to the sense that they give (Krippendorff, 2011), has been accepted by DDI.

DDI focuses on a process producing radical innovation through design (Verganti, 2009), "where innovation starts from the comprehension of subtle and unspoken dynamics in sociocultural models and results in proposing radically new meanings and languages that often imply a change in sociocultural regimes" (Verganti, 2011, pg. 387).

This then leads to the development of new breakthrough innovations in products' meanings (Dell'Era et al., 2010). Verganti builds on Krippendorff (2006) suggesting that the etymology of design is based on the Latin word designare that "one could say: design is making sense of things" (Verganti, 2003, 2008, 2009). Design is composed not only of the product's aesthetic appearance, but also of its functionality, semantic concerns and meaning. As a result, designers are inspired to innovate by exploring the ways in which communities of art, design, and innovation amalgamate to create radical and breakthrough products that are meaningful and delight the customers (Dell'Era et al., 2010, Utterback et al., 2006). A successful design conveys the meanings for all stakeholders who move a product through its life cycle, making it part of a social process, and giving rise to further developments (Krippendor, 2006). This seems to indicate that the product does not retain the same form and shape. Product meaning 
is therefore a link between the social aspects, specific languages, sets of signs, symbols and icons associated with the product (Verganti, 2008), and it indicates the reasons why a product is purchased at the individual (psychological and emotional meaning) and social (symbolic and cultural meaning) levels (Verganti, 2011). Creating new meanings also means innovation (Verganti, R., \& Öberg, 2013) because it proposes a new vision that redefines the problems worth addressing, it proposes a reason why people uses something, and a new value proposing, indicating what is relevant and meaningful in a market (Verganti, 2017).

The new product development' s goal is to create a product that could delight the customers, easy to use, elegant, neat, meaningful, sophisticated but simple, and able to capture the customers' attention (Utterback et al., 2006). Therefore, the product resulting from the design process is a product that has a unique combination of technology and market, and is meaningful for the customers (Dell'Era et al., 2011). It is a networked process of meanings and design languages (Buganza et al., 2009, Dell'Era et al., 2010, Dell'Era and Verganti, 2007, 2009, Verganti, 2008). In this perspective, value is created when a firm delivers a product to customers with a better design, performance, quality and experience (Utterback et al., 2006). These define the product's emotional and symbolic values, a personality and identity, which may easily go beyond the style (Verganti, 2009). Indeed, designers propose a vision, a product, an idea for the material suitable for the production, being careful about the client's identity, history, and geography. Designers can create breakthrough product meanings by acting on the semantic dimension of a product by capturing, transferring, recombining and integrating knowledge.

In Krippendorff (2006), language (spoken and written) is a complex concept, a culture, a mean that enables humans to coordinate their propositions, to agree for joint action, and to work in 
the construction and reconstruction of the realities. It is intended as a system of signs and symbols, individual expression, a medium of interpretation, a process of co-ordinating the perceptions and actions of speakers, a language use that directs attentions, frames perceptions, but it is also relational: everything said is said by someone in the expectation of being understood by someone else (Krippendorff, 2006). Through language, meaning is created, the fate of the products is determined, and the social praxis constructed. Meaning is intended as sense, as perception, as something that can be experimented with, and having imaginable uses (Krippendorff, 2006). However, language is not universal and meanings are subjective, context specific, with individual interpretation (Krippendorff, 2011). Whilst this position is interesting from the new product development perspective, it is also relative, since everything acquires contextual meaning: a knife cuts bread for dinner, but is also a deadly weapon (Krippendorff, 1989). This reflection does not take into consideration the fact that the design as sociotechnological object exists as a result of prior social constructions and contemporary social actions (Grint \& Woolgar, 1992).

In DDI this epistemological problematic is avoided by proposing a hermeneutic role for designers, who interpret and envision (Verganti \& Oberg, 2013). The management activities in this perspective are focused on the identification and nursing of one or more visionary and knowledgeable specialists (designers). Managers are persons with a highly differentiated knowledge (social, political, organisational, economic and technological), and they need to be able to create the conditions for certain technologies to arise (Verganti, 2009). Managers applying design driven innovation are aware that they should not simply follow the existing trends. They are making proposals with which they will modify the context, using designers as interpreters pursuing their own investigations and engaging in a continuous dialogue. Nevertheless, the socio-technical construction cannot be avoided, because in DDI the dialogue 
creates the design discourse. The design discourse understands the reality of the users, design becomes a language that is made circulated; the design becomes performative and the designers have a perlocutionary force (Krippendorff, 1989). This means that meaning is situated and cognitively constructed in the relationship. By avoiding to tackle the epistemological problem, This standpoint not only creates indeterminacy on managing the meaning - leaving it to the end users- but also moves the meaning construction in an ontological realm (what is the meaning made of) rather than epistemological (what do we know about the meaning).

In fact, we suggest solving this indeterminacy by using ANT. Research on performativity in ANT (e.g. Callon 2007) is based on sociotechnical "agencement", (arrangements provided with agency), and performation (Callon 2007), thus utterances are referred as accounts, enabling and restricting agency (Law, 1996), posing questions of the relationship between who and what gets addressed to account (Munro, 2001), of the spacing and timing of the accounts (Munro, 2004) and what they produce. Therefore, this means that compared to Krippendorff's argument, researching meaning in ANT is not only a linguistic operation, but a translation from one mode of existence (such as sentence) to another one (such as data for the analysis/ meaning). The word translation means "displacement, drift, invention, mediation, the creation of a link that did not exist before and that to some degree modifies two elements or agents" (Latour, 1994: 32). Researching translation through modes of existence in this way becomes an ontographic investigation, i.e. practical ontology attitude rather than an ontological position. Indeed, ontology settles questions of identity and difference through a 'pre-theoretical decision', while the empirical research and epistemology remain open to distinct resolutions of what counts as identity and difference in the practical settings studied (Lynch, 2013). This positioning provides a good foundation for the research on meaning and the relation between meaning and the materiality of the design, and on the role of managers in creating accounts, 
and how the accounts are displaced in time and space, for long-lasting products. This provides a bridge across the current literature.

\section{Actor Network Theory}

ANT is interested in understanding how society is constructed (Callon \& Latour, 1992). Using this framework goes back a number of decades (Latour, 1987), but has more recently gained momentum in the study of design (Wilkie, 2016), and has been used in architectural design (Yaneva, 2009), in user-centred, human-computer interaction, and in participatory design (Callon, 2004). In ANT, the social is built by local interactions, existing only within the network and in the translations, making the social unstable, not durable, temporary, and chaotic (Latour, 2005). Human and non-human actors are constantly working to stabilise reality. In ANT, design can be considered the outcome of the process of constructing things by translating interests and goals, enrolling and mobilising actors (both humans and non-humans) belonging to the socio-technical network and inscribing characteristics, values and behaviours (Akrich, Callon \& Latour, 2002b).

From this perspective, design is not the discovery or an act of a genius, but the outcome of the work done by the actors enrolling other actors, analysing, prototyping, interpreting the inscriptions, the trials with the machines and the materials (Latour, 1987). During the process, the spokesperson, the actor who is speaking on behalf of the design, emerges. He/she works to create a stable network of human and non-human actors across social, organisational, and technical domains, and displaces value through the marketing devices. As an emerging action, meaning creation can be inferred in ANT, as an ongoing process in the network. The meaning of design can be seen as a mishmash of decisions that cannot wait in an environment of complex changing markets and customer tastes, in which actions cannot be planned or predicted in any mechanical way (Akrich, Callon \& Lator, 2002a). The meanings of the objects are produced, 
not given, by the social interactions; thus, the semiotic meaning of design is not a priori determined, but constructed in the network by engaging a multitude of the complex microprocesses that happen in the design creation, development, launch, and post launch phase, making it performative through the relations (Latour, 1999).

To summarise the theoretical background (DDI) and the analytical framework (ANT), the designer through a socio-cultural network creates product's meaning (Verganti, 2009). However, ANT would suggest that it is both human and non-human actors that co-construct meaning perpetually. The meaning is created in the accounts that are mobilised and they acquire an agency, they act upon the consumers through a translation process.

\section{Method}

In order to collect the data for the case study, the first author conducted a three-year (20112014) ethnography, being active in the field for two years and returning to the organisation occasionally in the third year for follow-up questions.

The organisation producing the Serie7 was selected because it manufactures iconic design products and at the same time proposes new innovations annually. In collaboration with the organisation, the initial research aimed to establish how the Serie7 chair had been so successful over many decades. In particular, exploring how design emerged and how the company manage successful products, whilst in parallel continually proposing new innovative ones. Through familiarisation with the firm and data the research question was refined to one focused on product value and meaning. Four designs were analysed (the Ant, the Egg, the Serie7, the Ice). Whilst the analysis was performed for all the designs, in this paper we decided to focus on the Serie7, designed by Arne Jacobsen as the case object because it is the most sold chair in the world (Faith, 2013) with over 7 million items sold, and considered the work on the meaning 
conducted by the company particularly interesting, given that the plywood chair did not change the shape and the materiality during the years.

The researcher was provided access to the firm, allowing on-site observations and access to the museum, with archives of written material, minutes from board meetings, scrapbooks and publications, including: marketing material, letters, pictures, newspaper and magazine clippings and brochures. To gain external validity, a steering committee, with two managers from the company, met the researcher four times over a period of 2 years. During weekly site visits, formal, scheduled semi-structured interviewees [appendix 1] $(n=22 ;$ Table 1) and informal ( $\mathrm{n}=25)$ ad-hoc interviews were conducted, lasting between 60 and 150 minutes. Five of the formal interviewees were conducted twice. Extensive conversations at the lunch table and during coffee breaks were added to the data corpus. Informal conversations were first noted in a diary and then digitally transcribed.

Additional background information about the history of the chairs was collected from recorded radio, television documentaries, and documents collected in the design museum in Copenhagen, Victoria and Albert Museum in London, and St. Catherine College in Oxford. This material was ordered into a database. Records were translated from Danish, Norwegian, French, Spanish and Italian into English. For each record, details on the source, content and other signifiers were recorded in the database. 


\begin{tabular}{|c|c|c|c|c|c|}
\hline Date & Position & Function & Date & Position & Function \\
\hline June 2011 & Design manger & Architect & Nov 2011 & FH designer & Cabinetmaker \\
\hline June 2011 & FH designer & Cabinetmaker & Nov 2011 & $\begin{array}{c}\text { Librarian at } \\
\text { Design museum }\end{array}$ & Historian \\
\hline June 2011 & $\begin{array}{l}\text { Consultant at the } \\
\text { DK Design } \\
\text { Centre }\end{array}$ & Historian & Sep 2012 & HR manager & Business \\
\hline June 2011 & $\begin{array}{l}\text { Large design } \\
\text { shop }\end{array}$ & & Oct 2012 & CFO & Finance \\
\hline June 2011 & Brand Manager & Marketing & Oct 2012 & $\begin{array}{l}\text { Former design } \\
\text { manager }\end{array}$ & Architect \\
\hline June 2011 & Head of Design & Architect & Oct 2012 & $\begin{array}{c}\text { Marketing } \\
\text { manager }\end{array}$ & Marketing \\
\hline June 2011 & Graphic Design & Design & Oct 2012 & Design manager & Architect \\
\hline June 2011 & Brand Operations & Business & Feb 2013 & $\begin{array}{l}\text { Librarian at St. } \\
\text { Catherine Coll. }\end{array}$ & Archeologist \\
\hline July 2011 & Designer 1 & Designer & March 2013 & Design manager & Architect \\
\hline July 2011 & $\begin{array}{c}\text { Mgr. auction } \\
\text { house in Milano }\end{array}$ & $\begin{array}{l}\text { Historian of } \\
\text { Art }\end{array}$ & March 2013 & $\begin{array}{c}\text { Marketing } \\
\text { manager }\end{array}$ & Business \\
\hline Oct. 2011 & $\begin{array}{l}\text { Personal } \\
\text { Assistant to the } \\
\text { CEO }\end{array}$ & Engineering & March 2013 & $\mathrm{CFO}$ & Finance \\
\hline
\end{tabular}

Table 1: Overview of the 22 formal, scheduled interviews.

To analyse the multiple sources of data a two-part process was followed. First, a product life cycle (PLC) was drawn by bringing together the sources of data. Once the PLC was drawn, four episodes (Latour, 1987) as unit of analysis were identified. In this case, the episodes correspond to changes in the PLC: product development, introduction, increase of sales, and decline in sales. Second, all interviews were transcribed, coded and analysed using Dedoose, a software to analyse qualitative data. A formal thematic coding process (Saldana, 2011) was used, and themes were aggregated using Actor Network Theory framework (as introduced above): for each episode, the spokespersons, the markets, the constructed meanings, and how they were translated into values were identified. The focus on meaning creation is on the work conducted by the managers, on which meaning they constructed and how they frame it for the market. Using the ANT review, we analyse meaning creation as the hard work of the manager 

understand meaning is an interesting research investigation but outside the scope of this paper.

The episodes chosen for this paper were initially presented to and discussed with the company. It was decided to focus on the new product development and the processes that led to the development of such a breakthrough product for the time (1953-1957). Then, an introduction to the market in which the manager worked closely with the designer to promote the chair (1958-1974); a third episode characterised by a change in the ownership structure (1975-1982), and a final episode that started since the new CEO was hired until the design manager that started with him left (2002-2015). The 80s and 90s were not considered for the analysis; in fact, both the interviews and the secondary data suggested in this period the company decided to focus on selling a larger amount of chairs by focusing mainly on price reduction, and we do not have other data regarding this period apart from discounts granted for larger purchases. Indeed, the management decided to focus on high production, cheaper chairs, this was a result of fashion, sell chairs in this era in which cost was the king. This approach was not considered meaningful strategy, thus in the $4^{\text {th }}$ episode the design manager reacted to it.

\section{Analysis}

The analysis is presented as a narrative, as commonly ascribed by ANT theorists (Latour, 2005), moving through the four episodes. Narrating is a matter of negotiating boundaries between the researcher and data. It is an analytical as well as a practical undertaking of decoding (describing) of facts that are matters of concern (Latour, 1987). Therefore, narration is more than a simple explanation or description. This approach to analysing the design process is uncommon in the design management literature, which is more commonly associated with a stage process (Borja de Mozota, 2003). 


\section{Episode 1 (1953-1957) - Design of the Serie7 chair}

In this episode, we are analysing how the Serie7 was designed as a reaction from a previous innovative chair that disrupted the language of what should be a good chair; however, the customers did not appreciate the new aesthetic that was disrupting the traditional one. Instead of compromising the design, the designer decided to create a new chair, the Serie7.

The Serie7 was the second chair made of plywood to have been designed in Denmark (Barnstone, 2004). The first one, the Ant, was considered to be a radical innovation as it was the first to use plywood in Europe, a material developed in the 1930s and refined during the Second World War. The American designers Eames and Sareenen were first to use the material to make furniture in the late 1940s. The manager of Fritz Hansen saw the chairs in USA and brought a sample to Denmark to study them.

This is how Arne Jacobsen learned about the new material and developed it to make the Ant.

The Ant received very positive and enthusiastic reviews in the newspapers and by Danish architects. The customers, however, were not satisfied with the design as it consisted of three legs and no armrest: they wanted to have the same chair with four legs and armrest. Arne Jacobsen refused to add the fourth leg and armrest, "Why 4 when 3 are sufficient? ${ }^{i}$ " He affirmed in an interview. Instead of adding the armrests to Ant - which would have compromised the design (the backrest needed changing to support the weight of the armrests) ${ }^{\mathrm{ii}}$, he decided to design a new chair.iii

In 1955, Arne Jacobsen, together with the manager Søren Hansen, took account of the critique and translated them into the Serie7 to enrol the dissident customers. The chair was presented as a new ultra-modern chair, and the designer inscribed the qualities (Akrich, 1992) and 
features (Latour, 1994) of being an ergonomic (promoted by Saarinen and taught at the university by Kaare $\mathrm{Klint}^{\mathrm{iv}}$ ), organic, stackable, functional chair. The shape was translated from the DAN chair, a chair that was designed by S. Hansen and stayed in production for two years. The 7 shape was a new visual shape, harmonious, and built using the new production technique. The Serie7 resulted with its four legs and armrests suitable for different environments, including living rooms and offices. Therefore, the chair was not only a table/ kitchen/ office chair, but it was versatile enough for different purposes. The process for designing the new chair was much unarticulated, based on prototype. ${ }^{\mathrm{v}}$

At the time, Jacobsen explained the meanings of the new design and how it would satisfy the unmet needs of the potential customers:

"Real estate has gotten smaller and smaller. Furniture consequently also has to take up less space. I have made my chairs so that they can be stacked and leave the floor open. This is very important in private homes, and imagine what it means in a lecture hall. This chair took me a year to make before I dared to let it out. A large and costly apparatus is put in motion when a chair is to be manufactured serially. I myself stood and moulded it to achieve the right curves, which are decisive for the seating position. We cannot see the cut, but we do feel it is right if we rest in it. Then we can make the chair's appearance correspond to our view of what looks good" (interview to Arne Jacobsen, published in Thau and Vindum, 1975).

Fritz Hansen had a stable and sustainable business, with offices in Copenhagen and New York. It was among the first companies in Denmark to work with architects and cabinetmakers ${ }^{\mathrm{vi}}$. Søren Hansen, as spokesperson of Fritz Hansen Company, supported this new industrial approach, agreeing to collaborate with Arne Jacobsen. In 1954, Fritz Hansen opened a new 
factory in Copenhagen, to expand the production of the plywood chair. Another new modern manufacturing production site was opened in Allerød to increase the productive capacity. This allowed more chairs in their portfolio. The Serie7, thanks to the manufacturing modernisation, was rapidly produced. Fritz Hansen as production manager facilitated adoption of the new industrial technology, working actively to develop the machinery necessary to work with plywood and expand the industrialisation process.

This created a new feature for the chair: it was industrially made, rather than made by a skilled, cabinetmaker, but still have high quality and considered democratic, since more families could afford it because it was sold at a lower price compared to the artisan-made.

In an interview for the newspaper Politiken, Søren Hansen affirmed that this kind of industrial production was the highest standards for the industry. He considered his company to be a pioneering furniture manufacturer. The machines were built following design logic: the designer came up with an artistically beautiful shape, then, the factory modified the machinery accordingly to allow production. ${ }^{\text {vii }}$ Soren Hansen, the manager, was concerned with having a chair suitable for high volume mass production to increase the profits by reducing effort per hour and per chair, decreasing the production cost and the sale price, so the number of items sold could increase, without impairing the quality and the comfort. He communicated through the press the meaning of industrial production. The expansion of the factory facilitated the marketing (by the designers at conferences) of the chair in both Northern Europe and in USA. In USA, the chair was presented as "organic" since the Eames' and Sareenen's chair were described as such and it wanted to be accepted by the market that was interested in modern furniture. 
Arne Jacobsen, the designer, was aware of the power of the press for communicating the qualities and proposing new meanings to make his designs valuable, and "he did not draw a single line without informing the press" (Thau and Vindum, 1975). Arne Jacobsen worked to promote features: being stackable, lightweight, good quality, organic, and comfortable in every situation. The Serie7 was also designed thinking about the needs of the Danish families as indicated above. The Serie7 maintained the features of the Ant in terms of quality, good seating, novelty, organic design, innovative, beautiful, but with armrests and four legs, and selling for a good price. According to the press, the chairs designed by Fritz Hansen provoked a good feeling when looking at it. ${ }^{\text {viii }}$ The following table was inspired by Verganti (2017), and presents the meaning of the chairs at the time and how the management proposed a new meaning through a translation process (connecting otherwise disconnected things) through the features.

\begin{tabular}{|l|l|l|}
\hline Translation process & $\begin{array}{l}\text { Connecting home furniture aesthetic with industrial } \\
\text { production and the new era of economic dynamism }\end{array}$ \\
\hline Feaning of the chairs in the & Meaning of the Serie7 \\
market
\end{tabular}

Table 2: Translations of the product life cycle for episode 1 (1953-1957)

\section{Episode 2 (1957-1974)}

This episode is characterised by the displacement of chairs in international markets. After the introduction of the Serie7, Fritz Hansen's management intended it to become the market leader by exploiting the improved production capacity of the Serie7 and changing the marketing strategy. Due to the favourable economic situation, people from the middle class could afford 
to buy designer furniture. The message communicated through the press and at the various fairs was the willingness to break from the past, resulting in a change in the architectural and design language. Søren Hansen and Arne Jacobsen were always present at exhibitions of the chairs to communicate the Series 7 values. The chairs were represented in small flats, suitable for small buildings, but also in large canteens, meeting rooms, and municipality rooms. The chairs were presented as communicative, intimate, pleasant, suitable for different tastes, and transmitting good feelings. They were able to bridge the gap between old and the new since they were represented either in old or modern flats surrounded by old and modern furniture; they were warm, Danish, for families but also businesses, stackable, ergonomic, durable, and of good quality. The interior designers described the Serie7 as ideal furniture for the "ideal family". The chairs were more expensive than others but more durable. Notably, Søren Hansen described the chair as being manufactured rather than traditionally handcrafted by a cabinetmaker. The Fritz Hansen chair's won a number of awards including the Grand Prix at the Milano Triennale in 1957. Winning the Grand Prix had a considerable impact on sales the following year, making Jacobsen and Hansen's furniture well known to the public for their innovative design and language. Jacobsen presented the chairs and the portfolio of the chairs designed by him and Fritz Hansen at the final conference. This impacted on markets globally with a Japanese commercial centre using the Fritz Hansen Serie7, Egg and Grand Prix as windows for the Matsuya store in Tokyo. ${ }^{\text {ix }}$

As a result of this strategic aim and publicity around the Serie7, Arne Jacobsen was invited to propose a modern design for St Catherine College, Oxford University, built among the ancient colleges of Oxford. St Catharine College's master, Historian Alan Bullock, hired Jacobsen because he was not affected by Oxford's "almost suffocating feeling of being unable to escape from the past. ${ }^{x}$ " Jacobsen designed the college and dabbled with the interiors. Every room had 
a Serie7 or Ant. This was consistent with the Hansen's strategy to export a new style of furniture, and enrol the UK market into this new furniture and to give each household a good chair. Following the achievements in the UK, Arne Jacobsen was invited to exhibitions organised in London at the Royal Institute of British Architects to present his design.

In 1966, Christine Keeler, a model involved in the impeachment of Mr John Profumo, was photographed naked on a copy of the Serie7. Even if it was a copy, the picture circulated around Europe and brought the chair to the forefront of the public's imagination, catalysing sales.

As a result of these successes, exports of Danish furniture increased globally with exports of Fritz Hansen counting for $55 \%$ of the whole worlds' production of chairs. Markets included Germany, UK, France and the USA with Søren Hansen opening a new showroom in New York. He actively engaged New York customers by giving speeches in high society circles about Danish Design and furniture quality. The Danish architect, Morgens Kock, organised the first Danish furniture exhibition in 1960 in the USA. Kock wanted to displace the new Danish furniture language. The Americans understood the exhibition and were enrolled in the language, deciding to buy Fritz Hansen chairs as corporate chairs, which made the sales increase considerably.

\begin{tabular}{|c|c|c|}
\hline \multirow[t]{2}{*}{ Translation process } & \multicolumn{2}{|c|}{ Bridging the gap between old and new furniture } \\
\hline & $\begin{array}{l}\text { Meaning of the chairs in the } \\
\text { market }\end{array}$ & Meaning of the Serie7 \\
\hline Features & $\begin{array}{l}\text { Plagiarism } \\
\text { Hand-craft } \\
\text { Design is for small markets }\end{array}$ & $\begin{array}{l}\text { Warm, new, modern, Danish, for } \\
\text { families but also businesses, } \\
\text { stackable, ergonomic, durable, and } \\
\text { of good quality. The interior } \\
\text { designers described the Serie7 as } \\
\text { ideal furniture for the "ideal } \\
\text { family". The chairs were more } \\
\text { expensive than others but more } \\
\text { durable. } \\
\text { Communicative, intimate, } \\
\text { pleasant, suitable for different } \\
\text { tastes, and transmitting good } \\
\text { feelings. }\end{array}$ \\
\hline
\end{tabular}


Table 3: Translations of the product life cycle for episode 2 (1958-1974)

\section{Episode 3: the oil crisis (1975-1982)}

During this episode, the sales of the Serie7 increased drastically. At the beginning of the 1970s, Peter Lassen, new CEO of Fritz Hansen, invested in the designer, Verner Panton, as a new funkier designer following the death of Arne Jacobsen in 1971. The chairs of Verner Panton were pop and plastic, considered to be a new and interesting material, and the company invested in changing production from wood to plastic. However, as a result of the oil crises, raw materials increased in price almost leading Fritz Hansen to collapse. The company was subsequently acquired by the Scandinavia Tobacco holding.

During the oil crisis production was changed from plastic to wood and plywood, privileging the big commissions with the use of plywood, considered a green resource (clean, not as polluting, sustainable) and cheaper. The CEO and the design manager at the time decided to create a new meaning for the wood: from construction material, it was translated into sustainable material and long lasting. Due to the criticality of the plywood material to the business, and how it could affect quality of manufacturing, the company decided to open a new school for teaching the young employees how to work with the wood. Production reduced the variety of models to reduce the cost of changing the moulding forms; focusing only on the Serie7 family as a result of its global success. Following almost collapse as a result of the oil crises a number of decisions were made, and it was decided to re-design the meanings of the Serie7, change the aesthetic of the chair by proposing new colours that could facilitate the framing of the new meanings and creating new associations, and a break with the previous period that lead to the bankruptcy. 
In a newspaper interview preserved in the internal report, Peter Lassen informed the market of this green approach:

In the 60 's people thought of furniture as something you got one day and changed the next and therefore were not allowed to be too expensive. This viewpoint is still present, but the philosophy of recycling is on the increase. When we produce and sell more it is because the consumers are becoming more reasonable. Economic people do not like to throw things away. And you don't throw our things away. They can be used for generations, and are therefore recyclable. (Reflections written by Peter Lassen in an internal report)

The Serie7 acquired a new meaning through the oil crises: eco-friendly, through the features of being flexible, Danish, resistant, high quality, reusable in the sense that it can be used by different people and the mothers were giving it to the daughters or sons once they moved out from their home, and sustainable because it was made of wood and not of plastic. The increase in oil prices, a new actor that appeared in the company's network, changed its configuration. The company decided to translate the Danish feature of quality and long lasting for the Middle East Countries, which became very wealthy and willing to pay for design quality. These countries invested in large infrastructure projects including schools and hospitals, which were furnished with the Serie7 and other Fritz Hansen's designs.

Throughout this episode, the environmental movements mobilised the public's attention on the pollution caused by plastic and manufacturing waste. To take advantage of this, Peter Lassen mobilised the sustainable values of wood as an alternative to the plastic chairs that were polluting in order to enrol the environmental group. Being of good quality and resistant, therefore, these products did not have as a drastic impact on the environment, because they 
were long-lasting and minimised waste. Alongside this, the chairs were associated with tradition rather than wasteful, and feature rich modern chairs. Whilst the product itself was not redesigned, the values attributed were reconstructed.

\begin{tabular}{|l|l|l|}
\hline Translation process & Eco-friendly and long lasting chair \\
\hline Features & $\begin{array}{l}\text { Meaning of the chairs in the } \\
\text { market }\end{array}$ & $\begin{array}{l}\text { Meaning of the Serie7 } \\
\text { fashion-fads, }\end{array}$ \\
\hline
\end{tabular}

Table 4: Translations of the product life cycle for episode 3 (1975-1982)

\section{Episode 4: Iconic and Scandinavian design of the Serie7 (2002-2015)}

In 2013, the Triennale in Milano displayed the Serie7 in the dedicated area: Danish Design, and the design featured the Serie7 into as a classical, Danish and Scandinavian. The Serie7 has been revived by the museums, as portrayed by this design manager in relation to a 1950's exhibition:

There are also design trends of course, suddenly the '50s are very trendy or certain material is very trendy, or the design language is very trendy.

Numerous museums around the world have in their collection the Serie7, not only as a sitting chair, but also as a model to exhibit, including the design museum in Copenhagen, Denmark, Victoria and Albert Museum in London, SFMOMA in San Francisco, and MOMA in New York. 
In 2002, Louisiana Museum, located north of Copenhagen, held an exhibition on Arne Jacobsen, and the company provided material and helped in curating. The exhibition mobilised the customers and the press, and they started to have interests again in Arne Jacobsen and his design. This translated the chair from being functional to be artistic. The translation mobilised some architects to write books and catalogues about Scandinavian Design, Arne Jacobsen and the Royal Hotel in Copenhagen.

In 2005, the management of Fritz Hansen decided to collaborate with the Danish AIDS Foundation to coordinate a fundraising auction. The brief for the exhibition was: how would the Series 7 Chair look today if you were given a free hand to design it? The designers who were enrolled in this call were Birger Christensen, Bisazza, Camper, Diesel, Georg Jensen, GStar, Hugo Boss, Hummel, Louis Vuitton, Mandarina Duck, Missoni, Kris Ruhs, 10 Corso Como, Paul Smith and Royal Copenhagen.

Campers redesigned it as an idyllic swing; Royal Copenhagen's hand-painted floral arrangement with gold inlay and Paul Smith inscribed the classic British stamps in a Union Jack pattern. The collection was toured in London, Milan, Copenhagen, New York, and Tokyo. It ended with the auction for the fundraising for the Danish AIDS Foundation to combat HIV in Africa when auctioned at Bruun Rasmussen. In 2006, the chairs were exhibited in Triennale, Milano during the design fair, which reinforced the translation process. In 2007, the chairs were exhibited again for another fundraising event. It was hosted in California and organised by dkVOGUE in collaboration with the company.

However, the 2008 financial crisis, a new actor in the company's network, changed the configuration of the network and made the relation with the customers very fragile: during a crisis people do not buy expensive furniture. To substantiate this, the company re-enforced the 
meaning of the chair being long-lasting. Here, the design manager describes how the chair was translated to the private market to

keep them for a long time, and gives them to kids and grandchildren ...it doesn't sound like a good business model but ...I think it makes sense for us and it is also part of our CSR strategy that we want to prove the sustainable quality, we want to be sustainable without compromising the quality of the products, we believe that exclusive design, high quality, stability is part of the same solution and this is that we are working on (interview to the design manager).

In this perspective, the company is working with the meaning of the product to improve the sustainability by engaging in creating long-lasting products, having a positive economic and environmental impact (Esslinger, 2011).

Also in the USA, a new actor created new relations between the company and the customers: the second-hand market and collector's market in selling and buying Scandinavian Design items. The former design manager commented:

Other factors that have influenced the recent increase in interest in modern classics is the fact that originals and early production models are highly collectable, they are still affordable and are proving to be a good investment. (...) Mainstream shops are also full of these classics- sometimes they are original designs copies, today under license, and sometimes they are cheap, but convincing, imitations- so it is clear that the appetite for modern furniture is greater than ever (...) for others it is the sculptural and beautifully crafted designs in wood that are associated with the Scandinavian Design. (Interview to the designer 1) 
Therefore, the meaning Scandinavian Design has contributed to strengthening the relationship of the customer to the Serie7, even if second-hand. But the growth of this market re-assured the customers buying a new one, as it could be re-sold in the case of difficulties.

In 2012, the company initiated a new translation by revitalising the concept of furniture made of wood, not coloured, authentic and not hiding the beauty of the material. In an interview, the brand manager affirmed:

This is also part of revitalising the product. Few years ago, we introduced something called design colours. Not completely new colours, but an initiative where seven young designers were asked to decorate the chair to give a fresh look, to link to something that is not always old. It is very well known in some market, like in Denmark. Sometimes we had price issues, so the local market needed a bigger effort for communicating the quality, the better quality compared to competitors and copies. It is sometimes a matter of finding a new story (interview to the brand manager).

Two events created problems in sales: the decision to increase prices and the economic crisis. The increase of prices was a strategy decided by new CEO to position the chairs on a more exclusive market, focusing on the private market rather than contractor. According to the former design manager, who was working there at the moment of transition, the motivation was to reposition to the chair, because the margins were low in case of big orders:

Prices have to be incredibly high, our philosophy was: maybe we will no longer have those big orders for the 7 chair of 500 or 1000 or 1500 chairs; it doesn't matter, because when we sell so many chair, the discount is so high that, even if we sell 2000 chairs, we do not earn a lot of money, instead it is much better idea to sell 300 chairs at a higher price (...) But that has been a conscious strategy at Fritz Hansen, not selling high 
volumes without profit. Instead, selling much lower volumes with higher profit and establishing the company as a luxury brand (interview to the design manager, $2^{\text {nd }}$ round).

The design manager further explained the three values that were chosen to design the visual, emotional and irrational values and how they relate to the new meanings of the Serie7.

...We want our products to have a long life span. So we say that the long lasting value should not only be about high quality but should be strong, resist many years but also be long lasting visually. It is also genuine, honest; we want our products to be real materials (interview to the design manager, $2^{\text {nd }}$ round).

The Serie7 thus becomes honest, serene, calm, and Danish, high quality, cosy and with a particular attention to the use of sustainable material. The wood comes from certified forests; it is long lasting so there is limited waste. The standards for the production are high; the company has strengthened the surfaces through new lacquer. It is produced according to the European standards; they meet the requirements for all the different markets (public, schools, and private houses). The Serie7 is also described as classic and timeless, simple, easy to recognise, they are not stealing the attention from the architecture, they are described as having their own character; therefore, they can be displaced in totally different contexts.

Relating to the concept of the "Republic of Fritz Hansen" as the company as been re-named, the chair has been described by the CEO as democratic, conveying of good values, shared prosperity at home, which is central to the Scandinavian life. 
The strategy of the design department was, every year, to create a new product and to revitalise a new one. The revitalisation process is considered a new design process rather than a rebranding operation.

\begin{tabular}{|c|c|c|}
\hline \multirow[t]{2}{*}{ Translation process } & \multicolumn{2}{|c|}{ Danish and Democratic timeless Chair } \\
\hline & $\begin{array}{l}\text { Meaning of the chairs in the } \\
\text { market }\end{array}$ & Meaning of the Serie 7 \\
\hline Features & $\begin{array}{l}\text { Design for a mass market; } \\
\text { Design for the corporate } \\
\text { market; Designed by a } \\
\text { cabinet maker }\end{array}$ & $\begin{array}{l}\text { Honest, serene, calm, high } \\
\text { quality, cosy, sustainable } \\
\text { material, long lasting; } \\
\text { meeting the legal } \\
\text { requirements for all the } \\
\text { different markets (public, } \\
\text { schools, and private houses), } \\
\text { classic, simple, easy to } \\
\text { recognise, versatile. }\end{array}$ \\
\hline
\end{tabular}

Table 5: Translations of the product life cycle for episode 4 (2002-2013)

\section{Discussion and conclusion}

The analysis of the Serie7 case suggests that the value creation process is a conscious construction that occurs through the work of managers. The mangers framed the new and emerging meanings for the market by mobilising a different set of features. Deploying the literature on meaning creation and performativity, we could establish a relation between language form and materiality: the features are pledged to describing and explaining materiality, and the new meaning which is based on a translation process by connecting otherwise disconnected utterances/ features (for example industrial and traditional) is central. Utterances/features provide evidence for an interpretation of the claim of the manager, even though to accept or refuse it is in the hands of customers (Akrich, Callon and Latour, 2002a). This means that using ANT, we contribute to the previous discussion on meaning creation of Krippendorff, as context specifies and determines the utterance/features; and its use through 
the translation process is central to any account of the interpretative process. In fact, hermeneutics propose that innovation of meanings entails a double level of design: the whole user experience, and the product, without taking into consideration the context.

Through the four Serie7 episodes illustrated, the analysis demonstrates that the value creation is a result of a translation of meanings, which are continuously negotiated to customers and defined by the spokesperson. The meanings are recognised as a contingent, negotiated outcome of local and historical processes. For example, in episode 4 the CEO builds on the 50 -year period to market the traditional values with it becoming 'Danish' and 'timeless'. This illustrates how the product is redesigned, not in a traditional, incremental or physical way but, through meaning and with a consistent form and shape. From the analysis of the documents, it was also clear that the design manager suggested what the meaning was and was not. In the following table a cross case analysis is proposed:

\begin{tabular}{|l|l|l|l|l|}
\hline & $\begin{array}{l}\text { Episode 1 } \\
(1953-1957)\end{array}$ & $\begin{array}{l}\text { Episode 2 } \\
1958-1974\end{array}$ & $\begin{array}{l}\text { Episode 3 } \\
1975-1982\end{array}$ & $\begin{array}{l}\text { Episode 4 } \\
\text { 2002-2013 }\end{array}$ \\
\hline
\end{tabular}




\begin{tabular}{|c|c|c|c|c|}
\hline $\begin{array}{l}\text { Allies in the } \\
\text { network }\end{array}$ & $\begin{array}{l}\text { The network is } \\
\text { composed of a } \\
\text { complex } \\
\text { heterogeneous } \\
\text { network of } \\
\text { humans and non- } \\
\text { human actors. } \\
\text { The allies are } \\
\text { working for } \\
\text { adoption, the } \\
\text { production and } \\
\text { development of } \\
\text { the plywood and } \\
\text { the new chair }\end{array}$ & $\begin{array}{l}\text { Allies in the } \\
\text { network change } \\
\text { compared to the } \\
\text { previous episode. } \\
\text { New actors } \\
\text { mobilised to } \\
\text { displace the } \\
\text { chairs } \\
\text { (exhibitions, } \\
\text { prizes, new } \\
\text { buildings, } \\
\text { favourable ex- } \\
\text { change rate that } \\
\text { increased the } \\
\text { profits) and } \\
\text { others that are } \\
\text { creating struggles } \\
\text { (design } \\
\text { infringement, } \\
\text { copies) }\end{array}$ & $\begin{array}{l}\text { When actors } \\
\text { emerged, and } \\
\text { they were } \\
\text { destabilising the } \\
\text { network of Fritz } \\
\text { Hansen (the oil } \\
\text { prices, the } \\
\text { economic crisis, } \\
\text { the pollution } \\
\text { caused by the } \\
\text { industry, petrol } \\
\text { and plastic } \\
\text { materials). Peter } \\
\text { Lassen enrolled } \\
\text { these actors in the } \\
\text { network of the } \\
\text { Serie7, and they } \\
\text { contributed to } \\
\text { make it stronger } \\
\text { and increase the } \\
\text { sales }\end{array}$ & $\begin{array}{l}\text { The network in } \\
\text { this episode is } \\
\text { more fragile (e.g. } \\
\text { crisis and higher } \\
\text { prices) and others } \\
\text { that worked to } \\
\text { sustain it with the } \\
\text { museums' } \\
\text { exhibitions, the } \\
\text { reinterpretations } \\
\text { made by the } \\
\text { artists. }\end{array}$ \\
\hline Meanings & $\begin{array}{l}\text { Connecting home } \\
\text { furniture } \\
\text { aesthetic with } \\
\text { industrial } \\
\text { production and } \\
\text { the new era of } \\
\text { economic } \\
\text { dynamism }\end{array}$ & $\begin{array}{l}\text { Bridging the gap } \\
\text { between old and } \\
\text { new furniture }\end{array}$ & $\begin{array}{l}\text { Eco-friendly and } \\
\text { long lasting chair }\end{array}$ & $\begin{array}{l}\text { Danish and } \\
\text { Democratic } \\
\text { timeless Chair }\end{array}$ \\
\hline
\end{tabular}




\begin{tabular}{|c|c|c|c|c|}
\hline $\begin{array}{l}\text { Translation } \\
\text { process }\end{array}$ & $\begin{array}{l}\text { During this } \\
\text { episode the } \\
\text { plywood, the } \\
\text { material used for } \\
\text { the Serie7, was } \\
\text { developed and } \\
\text { the actor organic } \\
\text { design. Aalto } \\
\text { developed the } \\
\text { plywood as } \\
\text { handcraft } \\
\text { material; the } \\
\text { Eames developed } \\
\text { it to make it } \\
\text { bendable and } \\
\text { usable at the } \\
\text { industrial scale. } \\
\text { Søren Hansen } \\
\text { took it to } \\
\text { Denmark, and } \\
\text { together with } \\
\text { Fritz Hansen, } \\
\text { they developed to } \\
\text { make it suitable } \\
\text { for the local } \\
\text { timber and } \\
\text { developed a new } \\
\text { technique to } \\
\text { make it bendable } \\
\text { to manufacture a } \\
\text { chair with one } \\
\text { piece of wood. } \\
\text { The first chair } \\
\text { made of one } \\
\text { piece, the Ant, } \\
\text { translated into the } \\
\text { Serie7 because of } \\
\text { the complaints } \\
\text { from the } \\
\text { customers }\end{array}$ & $\begin{array}{l}\text { The Serie7 was } \\
\text { translated into the } \\
\text { representative of } \\
\text { the Danish } \\
\text { Design. Because } \\
\text { of the plant's } \\
\text { enlargement and } \\
\text { the high sales of } \\
\text { the Ant and } \\
\text { Serie7, the } \\
\text { increase of the } \\
\text { export, Hansen } \\
\text { and Jacobsen } \\
\text { designed and } \\
\text { produced new } \\
\text { chairs using the } \\
\text { same industrial } \\
\text { technique }\end{array}$ & $\begin{array}{l}\text { Peter Lassen } \\
\text { initiated the } \\
\text { translation of the } \\
\text { Serie7 as Danish } \\
\text { design, a chair of } \\
\text { good quality that } \\
\text { is sustainable, } \\
\text { resistant and } \\
\text { suitable in } \\
\text { different markets } \\
\text { (Europe/ USA/ } \\
\text { Middle East) }\end{array}$ & $\begin{array}{l}\text { The Serie } 7 \text { was } \\
\text { translated from } \\
\text { being a well } \\
\text { known chair, } \\
\text { suitable for any } \\
\text { use, to a high end } \\
\text { classical } \\
\text { Scandinavian } \\
\text { design, through } \\
\text { the creation of } \\
\text { the Re- public of } \\
\text { FH, the work of } \\
\text { the artists, and } \\
\text { the exhibitions }\end{array}$ \\
\hline
\end{tabular}

Table 6: Cross-case analysis.

In the analysis, the value creation is a process of creating meanings in the relations among actors, particularly between the managers, organisation and the market. In Krippendorff's theory the customers engage in a cognitive process and they create meanings, so it is an outcome of the end-user's work; in DDI, the designer proposes new meanings, and the 
customer make sense of them based on the ecological context. In ANT, the meaning is an outcome of the translation process, through which the designer, the design manager and the manager work actively to design new ones, create a connection with the customers and frame customers in accepting it.

The meanings can be accidental (Harman, 2009) because they are framed and built in the relationships (Latour, 1999). Value is generated from this process, it resides in the relations, it is emergent and can be moulded.

The meanings of the Serie7 were changed over the four episodes and the 50-year period, and are therefore enacted in a continuous process of reproduction (Law, 2004). From the analysis, it appears that the chair was successful in being in the market for 60 years due to the work of the design manager creating new meanings through a translation process and for the manager to frame them for the market. Meanings are not fixed but they change during the product lifecycle. The case shows that meaning creation can reposition the design in the market. This is a never-ending process, and companies need to act upon it, to propose a new meaning when the network of the current and accepted one becomes destabilised. Even if the faith of the product is in the hands of the customers (Akhich, Callon, Latour, 2002a), the company needs to actively design new meanings to ensure the product does not need to be abandoned as a result of it not being successful in the market, and the customers can be framed accordingly.

These findings strengthen the innovation literature. In design driven innovation (Verganti, 2009), value is generated in the social and cultural context, subjective and culturally determined; the value is associated with the meaning of the objects. Moreover, it also stimulates a critical thinking towards sustainability issues: working with the meaning of the product 
allows to develop a sustainability agenda as the company engages in creating long-lasting products, which have a positive economic and environmental impact.

Thus, we contribute to this perspective on design by proposing to use ANT in analysing meaning. We demonstrate that the design is constructed in a socio-technical network, and meaning is created through accounts in this network, which change. In Krippendorff's theory, design is perlocutionary, implying that design has a meaning that the customers make sense of through a cognitive process. In ANT, design can be considered as an actor that is enabling and restricting agency, thus it is necessary to create relationships between who and what gets addressed to with the account on meaning, which can change in spacing and timing. Therefore, compared to Krippendorff's argument, within ANT's framework it is possible to design meanings because they are not only a linguistic operation, as we use accounts to describe and know them, but also a translation to create connections between different features that the endusers would not have been able to make. Thus, whilst managers have an important role in framing the values for the end-users (Christiansen et al, 2010), designers and design managers design new meanings that will be consequentially translated in the market.

To build on these findings research is needed to identify the processes involved in redesigning values and meanings for products over time. Identifying methods to consciously redesign values and meanings, in the same way that many methods exist to redesign physical products for new markets, cultures and fashion, will strengthen companies ability to extend product lifecycles. This creates the additional benefit of sustaining product design infrastructures that are very costly to replace, for example manufacturing processes and supply networks. Moreover, this research was the work of managers to translate the meanings into new ones for the chair. Future research should investigate how the customers would accept the meaning. 
We also propose for further research to replicate the study for other long-lasting product to test the robustness of our proposition. This case does provide a compelling case to adopt ANT to explore these types of products further. The greatest challenge being access to sufficient data to facilitate a product that has been successful for an extended period. If data were available, it would be interesting to evaluate the impact of such strategy on CSR policies using meanings to sustain product infrastructures and enhance the sustainability agenda of organisations.

\section{References}

Akrich, M. (1992). The description of technical objects. In W. Bijker \& J. Law (Eds.), Shaping technology/building society: Studies in sociotechnical change (pp. 205-224). Cambridge, MA: The MIT Press.

Akrich, M., Callon, M., \& Latour, B. (2002a) The key to success in innovation part I: The art of interessement. International Journal of Innovation Management, 6(2), 187-206.

Akrich, M., Callon, M., \& Latour, B. (2002b) The key to success in innovation part II: The art of choosing good spokespersons. International Journal of Innovation Management, 6(2), 207225.

Barnstone, D. A. (2004) History of modern design. In History of modern design (pp. 61-62), Upper Saddle River, NY: Pearson Prentice Hall.

Bellini, E., Dell'Era, C., Frattini, F., \& Verganti, R. (2017). Design-Driven innovation in retailing: An empirical examination of new services in car dealership. Creativity and Innovation Management, 26(1), 91-107

Borja De Mozota, B. (2003). Design management: Using design to build brand value and corporate innovation. In Design management: Using design to build brand value and corporate innovation. New York: Allworth Press 
Buganza, T., Dell'Era, C., \& Verganti, R. (2009). Exploring the relationships between product development and environmental turbulence: The case of mobile TLC services*. Journal of Product Innovation Management, 26(3), 308-321

Buganza, T., Dell'Era, C., Pellizzoni, E., Trabucchi, D., \& Verganti, R. (2015). Unveiling the potentialities provided by new technologies: A process to pursue technology epiphanies in the smartphone app industry. Creativity and Innovation Management, 24(3), 391-414.

Callon, M. and Latour, B. (1992) Don't Throw the Baby out of the Bath School! A Reply to Collins and Yearley. In Pickering, A. (ed.), Science as Practice and Culture. University of Chicago Press, Chicago, IL, pp. 343-68.

Callon, M. (2004) The role of hybrid communities and socio-technical arrangements in the participatory design, Journal of the Center for Information Studies, 5(3), 3-10.

Callon, M. (2007). An essay on the growing contribution of economic markets to the proliferation of the social. Theory, Culture \& Society, 24(7-8), 139-163

Christiansen, J. K., \& Varnes, C. J. (2007). Making decisions on innovation: Meetings or networks? Creativity and Innovation Management, 16(3), 282-298

Christiansen, J. K., Varnes, C. J., Gasparin, M., Storm-Nielsen, D., \& Vinther, E. J. (2010). Living twice: How a product goes through multiple life cycles*. Journal of Product Innovation Management, 27(6), 797-827

Christiansen, J. K., \& Gasparin, M. (2016). Managing controversies in the fuzzy front end. Creativity and Innovation Management, 25(4), 500-514

Cooper, R., Bruce, M., Wootton, A., Hands, D., \& Daly, L. (2003) Managing design in the extended enterprise. Building Research \& Information, 31(5), 367-378.

Dell'Era, C., Marchesi, A., \& Verganti, R. (2010) Mastering technologies in design-driven innovation, Research-Technology Management, 53(2), 12-23.

Dell'Era, C., Buganza, T., Fecchio, C., \& Verganti, R. (2011). Language brokering: Stimulating 
creativity during the concept development phase. Creativity and Innovation Management, 20(1), 36-48.

Dell'Era, C., \& Verganti, R. (2007). Strategies of innovation and imitation of product languages*. Journal of Product Innovation Management, 24(6), 580-599

Dell'Era, C., \& Verganti, R. (2009). Design-driven laboratories: Organization and strategy of laboratories specialized in the development of radical design-driven innovations. $R \& d$ Management, 39(1), 1-20

Esslinger, H. (2011). Sustainable design: Beyond the innovation-driven business model. Journal of Product Innovation Management, 28(3), 401-404

Faith, D. (2013) Furniture by architects. Victoria, Australia: The Image Publishing Group.

Gabrielsen, G., Kristensen, T., \& Zaichkowsky, J. L. (2010) Whose design is it anyway? International Journal of Market Research, 52(1), 89.

Gasparin, M., \& Green, W. (2016). Framing values in design. In DRS2016: Design + Research + Society - Future-Focused Thinking (Vol. 3, pp. 881-894).

Gasparin, M. \& Neyland, D. (2017). We Have Always Been Modern(ist): temporality and the organisational management of 'timeless' iconic chairs. Organization In press

Green, W., \& Cluley, R. (2014). The field of radical innovation: Making sense of organizational cultures and radical innovation. Industrial Marketing Management, 43(8), $1343-1350$

Grint, K., \& Woolgar, S. (1992). Computers, guns, and roses: What's social about being shot? Science, Technology, and Human Values, 17(3), 366-380.

Harman, G. (2009). Prince of networks: Bruno Latour and metaphysics. Repress, Melbourne, Holzer, J. (2012). Construction of meaning in socio-technical networks: Artefacts as mediators between routine and crisis conditions. Creativity and Innovation Management, 21(1), 49-60. Kim, J., Lee, S., \& Park, Y. (2013) User-Centric service map for identifying new service 
opportunities from potential needs: A case of app store applications. Creativity and Innovation Management, 22(3), 241-264.

Krippendorff, K. (1989). On the essential contexts of artifacts or on the proposition that" design is making sense (of things)". Design Issues, 5(2), 9-39

Krippendorff, K. (2006) The semantic turn: A new foundation for design, New York: CRC Press Taylor \& Francis Group.

Krippendorff, K. (2011). Principles of design and a trajectory of artificiality. Journal of Product Innovation Management, 28(3), 411-418.

Latour, B. (1987) Science in action: How to follow scientists and engineers through society, Cambridge, Massachusetts: Harvard University Press.

Latour, B. (1994) On technical mediation- philosophy, sociology, genealogy, Common Knowledge, Fall V3(2), 29-64.

Latour, B. (1999) Pandora's hope: Essays on the reality of science studies, Cambridge, USA: Harvard University Press.

Latour, B. (2005). Reassembling the social: An introduction to actor-network-theory. New York : Oxford University Press, USA

Latour, B., Harmon, G., Erdélyi, P. (2011). The prince and the wolf: Latour and harman at the LSE. Alresford, Hants, S0249 JH, UK: Zero Books.

Law, J. (1996). Organizing accountabilities: Ontology and the mode of accounting. Accountability: Power, Ethos and the Technologies of Managing, 283-30

Law, J. (2004) After method: Mess in social science research, London: Routledge. Lynch M (2013) Ontography: Investigating the production of things, deflating ontology. Social Studies of Science 43(3): 444-462

Munro R (2001) Calling for accounts: Numbers, monsters and membership. Sociological Review 49(4): 473-494. 
Munro,R., (2004),'Punctualizing identity: time and the demanding relation', Sociology, 38: 293-311.

Puig de la Bellacasa, M. (2017). Matters of care: Speculative ethics in more than human worlds. University of Minnesota Press.

Saldana, J. (2011). The coding manual for qualitative researchers. London: Sage.

Thau, C., \& Vindum, K. (1975) Arne jacobsen, collection of interviews after his death, Copenhagen: Politiken.

Utterback, J. M., Vedin, B. A., Alvarez, E., Ekman, S., Sanderson, S. W., Tether, B., \& Verganti, R. (2006) Design-inspired innovation, New York: World Scientific Publishing.

Verganti, R. (1997). Order overplanning with uncertain lumpy demand: A simplified theory. International Journal of Production Research, 35(12), 3229-3248

Verganti, R. (2003). Design as brokering of languages: Innovation strategies in italian firms. Design Management Journal (Former Series), 14(3), 34-42.

Verganti, R. (2008) Design, meanings, and radical innovation: A metamodel and a research agenda, Journal of Product Innovation Management, 25(5), 436-456.

Verganti, R. (2009) Design-driven innovation: Changing the rules of competition by radically innovating what things mean. Boston, Massachusetts: Harvard Business School Press.

Verganti, R. (2011) Radical design and technology epiphanies: A new focus for research on design management, Journal of Product Innovation Management, 28(3), 384-388.

Verganti, R. (2017). Overcrowded: Designing Meaningful Products in a World Awash with Ideas. MIT Press.

Verganti, R., \& Öberg. (2013). Interpreting and envisioning-A hermeneutic framework to look at radical innovation of meanings. Industrial Marketing Management, 42(1), 86-95. Veryzer, R. (2005) The roles of marketing and industrial design in discontinuous new product development, Journal of Product Innovation Management, 22, 22-41 
Walsh, V., Roy, R., Bruce, M., \& Potter, S. (1993) Perspectives on design and innovation, Creativity and Innovation Management, 2(2), 78-86

Walsh, V., Roy, R., \& Bruce, M. (1988) Competitive by design, Journal of Marketing Management, 4(2), 201-216.

Wilkie, A. (2016) Introduction: Aesthetics, Cosmopolitics and Design. in: P. Lloyd \& E. Bohemia, eds., DRS2016: Design + Research + Society - Future-Focused Thinking, Volume 3, pp 873-880, DOI 10.21606/drs.2016.509

Yaneva, A. (2009) Made by the office for metropolitan architecture: An ethnography of design Amsterdam: 010 Publishers

\footnotetext{
${ }^{\mathrm{i}}$ i Information, 9.2.53: hvofor skal en stol have fire ben?

ii Internal document

iii hvofor skal en stol have fire ben?- news paper from 1957

iv internal catalogue

${ }^{v}$ explanation from the museum in Allerød and the various documents found written by the former design managers

${ }^{\mathrm{vi}}$ information from the balance sheets, the minutes from the meetings in the $1950 \mathrm{~s}$

vii machines fail to rule Design of Denmark, by Frances Van Hall (1956), newspaper article found in the warehouse of Fritz Hansen

viii for example, in the article Mobel vatleden n 3, 1957;

ix according to the article: Demokraten, 1964: oversættelse af en japansk annonce om danske møbler

$\mathrm{x}$ time magazine found in St Cathrine college
} 